\title{
Odor-mediated patterned responding as a function of delay of reinforcement but not reward-magnitude contrast
}

\author{
STEPHEN F. DAVIS and MELANIE S. WEAVER \\ Emporia State University, Emporia, Kansas 66801
}

\begin{abstract}
A two-phase experiment examining the production and utilization of odors under conditions of delay of reinforcement (Phases 1 and 2) but not reward-magnitude contrast (Phase 1) is presented. Appropriate odor-based patterning was shown only when animals entered an empty goalbox and reinforcement was subsequently delivered. Reducing reinforcement on selected trials (Phase 2) failed to result in the development of patterning by subjects entering a preloaded goalbox and did not significantly influence patterned responding that had already been established by those animals that entered an empty goalbox.
\end{abstract}

Dating from a seminal publication by Ludvigson and Sytsma (1967), it has been convincingly demonstrated (e.g., Prytula \& Davis, 1974, 1976; Seago, Ludvigson, $\&$ Remley, 1970) that rats are capable of learning a double-alternation pattern of reward/nonreward $(\mathrm{R} / \mathrm{N})$ (i.e., RRNNRRNN) under odor-maximizing conditons, but not under odor-minimizing conditions. Based upon such demonstrations, the existence of unique odors, characteristic of reward and nonreward experiences, has been proposed. Single-cell recordings from the medial olfactory bulb of the rat (Voorhees \& Remley, 1981) have supported this contention.

Following establishment of the presence and importance of such odors in controlling the rat's maze performance, it would appear to be of interest to determine under what conditions such odors are exuded and/or utilized. A considerable amount of research has been directed toward this objective. For example, Davis, Prytula, Harper, Tucker, Lewis, and Flood (1974), Davis, Prytula, Noble, and Mollenhour (1976), and Travis-Neideffer, Ludvigson, and Moreno (Note 1) have reported data suggesting that odors, especially those of nonreward, are deprivation-state specific; that is, odors produced under one deprivation state do not appear to be detected by animals being tested under a dissimilar deprivation state. Likewise, Davis, Burns, Howard, and Voorhees (Note 2) have shown that odors are produced and utilized under conditions of liquid reinforcement. Further, the results of a recent series of experiments (Davis, Whiteside, Bramlett, \& Petersen, 1981) have indicated that entrance into an empty goalbox, rather than the degree of rewardmagnitude contrast, is an important condition for the elicitation of odor cues.

This research was supported, in part, by a grant from the Research and Creativity Committee of Emporia State University to the first author.
The broad question of the relationship among reward magnitude, delay of reward, and odor production is prompted by the Davis et al. (1981) data. The present study sought to investigate one aspect of this relationship. Namely, would double-alternation patterning be developed when the same reward magnitude was presented on all trials? The Davis et al. (1981) data would suggest that, regardless of the complete lack of reward contrast, entrance into an empty goalbox would be sufficient to elicit odor cues. Hence, one would expect that double-alternation patterning would be shown only by those animlas experiencing reward delay (i.e., entering an empty goalbox).

To further investigate the possible interaction between reward magnitude and odor production, the second phase of the study involved reducing the reward on selected trials. If simply entering an empty goalbox is the important factor, then reducing the reward that is presented after the animal has entered the goalbox should not have any bearing upon the amount of odor that is produced. This being the case, it would be anticipated that patterning would be maintained at approximately the same level following reward reduction as was shown prior to the reduction. However, if there is some type of interaction between reward magnitude and odor production, then a reduction in reward might well result in the intensification of odors. It should be reiterated that patterning (i.e., nonreward odor production) would not be expected, during either phase, on the part of subjects encountering reward as they enter the goalbox.

\section{METHOD}

\section{Subjects}

Fourteen male Holtzman rats served as subjects. These animals had been previously trained under an eight-trial doublealternation $\mathrm{R} / \mathrm{N}$ schedule. During that training, the subjects were food deprived and maintained at $85 \%$ of their free-feeding 
body weights. This deprivation regimen was continued during the 2-week period separating this initial training from the present study, and during the experiment to be reported. All subjects were individually caged, with water freely available.

\section{Apparatus}

The apparatus consisted of a single straight runway $(11.4 \mathrm{~cm}$ wide $\times 12.7 \mathrm{~cm}$ high) with a gray startbox $(28.1 \mathrm{~cm})$, a black run section $(91.4 \mathrm{~cm})$, and a black goalbox $(30.5 \mathrm{~cm})$. Masonite guillotine doors separated the startbox and goalbox from the run section. Start, run, and goal times, produced by the activation of a microswitch located on the start door and the interruption of a series of photoelectric beams (located 15.2, 92.4, and $116.8 \mathrm{~cm}$ beyond the start door) were recorded on all trials. A plastic receptacle recessed into the end wall of the goalbox served as the goal cup. A thin sheet of transparent plastic covered the top of the alley to prevent the dissipation of odors.

\section{Procedure}

At the beginning of experimental testing, the two already established groups were randomly assigned to one of two reinforcement presentation conditions, immediate (I) and delayed (D). During both phases of the experiment, reinforcement was present in the goal cup for subjects in Group I when they entered the goalbox. During both phases, reward presentation for Group D occurred $15 \mathrm{sec}$ after the last photobeam in the goalbox was broken on Trials $3,4,7$, and 8 of the daily eight-trial sequence. On Trials $1,2,5$, and 6, Group D encountered reward in the same manner as did Group I; that is, reward was present as the subjects entered the goalbox on these trials.

Phase 1 testing lasted 6 days (48 trials). During this phase, $1245-\mathrm{mg}$ pellets were presented to all subjects on all trials. Phase 2 was also 6 days (48 trials) in length. During Phase 2, the reward magnitude on Trials $3,4,7$, and 8 was shifted from 12 pellets to 1 pellet for all subjects. Thus, the only difference between the two groups was the delay imposed upon Group D on Trials $3,4,7$, and 8 .

All subjects within a group received Trial 1 before Trial 2 was administered, and so forth. Further, the subjects within each group were run in the same fixed order on all days of the experiment. At the completion of each trial, the runway was swabbed with a damp sponge and allowed to air for $5 \mathrm{~min}$. Thus, the first subject in each group was tested in a clean, odor-free runway on all trials and, in essence, served as an odor donor for the following subjects. The order for running groups alternated from day to day.

\section{RESULTS AND DISCUSSION}

Prior to analysis and graphing, all latencies were reciprocated and multiplied by the appropriate constant to yield speed scores in meters per second. In all instances, the scores of the first (odor-donor) animal in each group were excluded from analyses and graphs. Visual inspection of these scores indicated that both subjects displayed nondifferential, fast speeds on all days of the experiment.

The eight daily speeds for each subject were reduced to four composite scores in the following manner: The first two trials were averaged to yield a Trials 1-2 average score, the third and fourth trials were averaged to yield a Trials 3-4 average score, and so forth. These average scores were used for data analysis and to determine group mean performance. Goal-measure performance for Groups I and D for the last day (TA) of the prior double-alternation $\mathrm{R} / \mathrm{N}$ training and the two phases of the present experiment is shown in Figure 1. The impression created by this figure would appear to be rather straightforward. Patterned responding (i.e., slow on delay trials, fast on nondelay trials) was rapidly established (by Day 2) by Group D. This patterning persisted until the termination of the experiment. On the other hand, Group I failed to display similar responding during either phase of the experiment.

Analysis of variance incorporating one betweensubjects factor (groups: I vs. D) and two within-subjects factors (days and trials) was performed on the start-, run-, and goal-measure speed data for Phase 1 and Phase 2. The start- and run-measure analyses for each phase failed to yield significant effects. Goal-measure analysis of the Phase 1 speeds yielded significance for the Groups by Trials $[\mathrm{F}(3,30)=3.44, \mathrm{p}<.05]$ and Groups by Days by Trials $[F(15,150)=2.11, p<.05]$ interactions. The Newman-Keuls procedure was employed to evaluate specific comparisons of interest, and it indicated that for Group D the Trials 1-2 and 5-6 averages did not differ from each other but were significantly $(\mathrm{p}<.05)$ faster on Days 2-6 than the Trials 3-4 and 7-8 averages, which, in turn, did not differ significantly from each other.

Analysis of the Phase 2 goal-measure speeds yielded significance for the Groups by Trials interaction $[\mathrm{F}(3,30)=5.29, \mathrm{p}<.01]$. As in Phase 1 , specificcomparison tests using the Newman-Keuls procedure

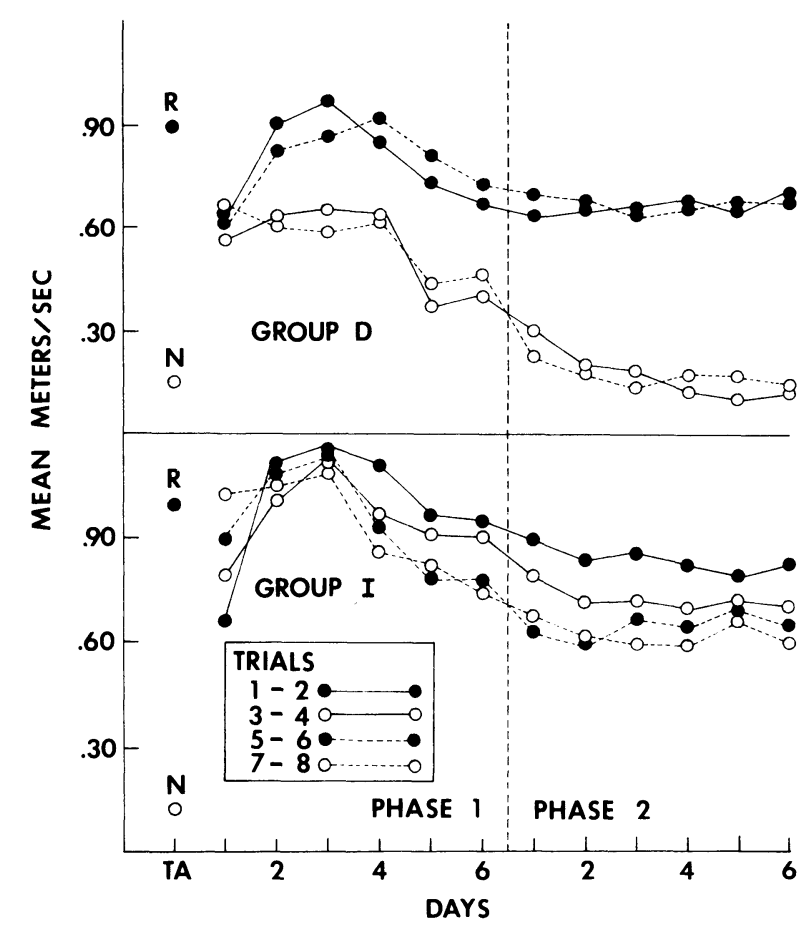

Figure 1. Mean goal speeds (in meters per second) of Groups I and D at terminal acquisition (TA) of prior doublealternation reward (R)/nonreward (N) training and during Phases 1 and 2. 
indicated that the Trials $1-2$ and $5-6$ averages for Group D were significantly $(\mathrm{p}<.01)$ faster than their Trials $3-4$ and $7-8$ averages.

Given the development of patterning by Group D and the lack of such patterning by Group I, it would appear reasonable to conclude that odors are exuded when an empty goalbox is entered, regardless of the magnitude of a reinforcer subsequently delivered during the goalbox-confinement period. Likewise, it would appear that the reward magnitude encountered upon entering the goalbox is not important for precluding the production of odors. The latter point is clearly reflected in the lack of change in goal-measure performance by Group I between Phases 1 and 2, despite the reduction in reward from 12 pellets to 1 pellet on Trials 3, 4, 7, and 8 in Phase 2. These results are certainly in accord with the data reported by Davis et al. (1981).

There is the suggestion, albeit nonsignificant, of a possible interaction between reward magnitude and odor production. This can be seen by comparing the Trials 3.4 and 7-8 speeds for Group D for the last day of Phase 1 with these speeds on the first day of Phase 2 (see Figure 1). The observation that these speeds are slower on Day 1 of Phase 2 suggests that the reduction in reward on these trials may have intensified odor cues in some manner. However, as an even more pronounced depression in speeds was also noticed during Phase 1 (Day 4 to Day 5), this interpretation must necessarily await further experimental validation.

Finally, some attention should be given to the rapidity with which patterning was reestablished by Group D following the 2-week interim period separating the original training from the present experiment. Appropriate responding was shown by Day 2 of Phase 1 . A similar finding was recently reported by Davis, Dudeck, and Weaver (1981). These findings indicate that, once established, the odor control of maze performance is well retained.

\section{REFERENCE NOTES}

1. Travis-Neideffer, M. N., Ludvigson, H. W., \& Moreno, R. Deprivation-state specificity of odor cues in the rat: Constraints vs. overshadowing. Paper presented at the meeting of the Southwestern Psychological Association, 1981.

2. Davis, S. F., Burns, R. A., Howard, A. J., \& Voorhees, J. W. Odor-based double-alternation patterning as a function of various types of liquid reinforcement. Unpublished manuscript, 1981.

\section{REFERENCES}

Davis, S. F., Dudeck, M. M., \& Weaver, M. S. Odor-based double-alternation responding and retention as a function of naloxone injection. Bulletin of the Psychonomic Society, 1981, 18, 275-277.

Davis, S. F., Prytula, R. E., Harper, W. E., Tucker, H. K., LEwis, C., \& Flood, L. Double-alternation runway performance as a function of inter- and intra-reinforcement odor cues. Psychological Reports, 1974, 35, 787-793.

Davis, S. F., Prytula, R. E., Noble, M. J., \& Mollenhour, M. N. Motivational specificity of the signal value of odor cues. Animal Learning \& Behavior, 1976, 4, 407-410.

Davis, S. F., Whiteside, D. A., Bramlett, J. A., \& Petersen, S. H. Odor production and utilization under conditions of nonreward and small reward. Learning and Motivation, 1981, 12, 364-382.

Ludvigson, H. W., \& Sytsma, D. The sweet smell of success: Apparent double-alternation in the rat. Psychonomic Science, 1967, 9, 283-284.

Prytula, R. E., \& Davis, S. F. Runway performance as a function of positively and negatively correlated olfactory cues. Psychological Reports, 1974, 35, 735-740.

Prytula, R. E., \& Davis, S. F. The relationship between the locus of odor cues and double-alternation responding in the rat. Animal Learning \& Behavior, 1976, 4, 352-356.

Seago, J. D., Ludvigson, H. W., \& Remley, N. R. Effects of anosmia on apparent double-alternation in the rat. Journal of Comparative and Physiological Psychology, 1970, 71, 435-442.

Voorhees, J. W., \& REMLEY, N. R. Mitral cell responses to the odor of reward and nonreward. Physiological Psychology, 1981, 9, 164-170.

(Received for publication September 21, 1981.) 